\title{
The Multiple Meanings of Jatio Sangsad Bhaban
}

\author{
Bayezid Ismail Choudhury ${ }^{1} \&$ Peter Armstrong 2 \\ ${ }^{1}$ Dept of Architecture, Khulna University of Engineering and technology, KUET, Bangladesh \\ ${ }^{2}$ Dept of Architecture, the University of Sydney, Australia \\ bayezid@arch.kuet.ac.bd
}

\begin{abstract}
Jatio Sangsad Bhaban, the National Assembly Building of Bangladesh, is an iconic building and architectural landmark designed by American architect Louis I. Kahn. Jatio Sangsad Bhaban was constructed between 1962 and 1983 and is located in the heart of Dhaka, the nation's capital. The extant literature on Louis I. Kahn's work suggests that Jatio Sangsad Bhaban is a significant architectural masterpiece. One of its most notable features is its architectonic quality, providing it with the grandeur of a modern monumental building. In this context, this paper aims to examine the underlying multiple meanings, that is, socio-political, cultural, historic and philosophical meanings of the Jatio Sangsad Bhaban building By constructing and summarising meanings, rather than exploring the physical building itself, this paper supports the notion of multidimensional perspectives of monumental architecture. The multiple meanings of iconic architecture through the lens of societal issues have been endorsed by many architectural critics. Accordingly, this paper considers the cultural, political, ethical and historical meanings of Jatio Sangsad Bhaban. Revealing and summarising other aspects apart from its architectonic dimensions is a new approach to understanding a widely acclaimed iconic building like Jatio Sangsad Bhaban.
\end{abstract}

Keywords: Jatio Sangsad Bhaban, National Assembly Building, Louis. I Kahn, Responsive Meaning, Dhaka.

\section{Introduction}

Jatio Sangsad Bhaban is the National Assembly Building in Bangladesh. It is an iconic building occupying an area of approximately 610 acres of land in the heart of Dhaka. ${ }^{i}$ Commissioned by Ayub Khan, the military dictator and then president of Pakistan, it is regarded as one of the most important buildings designed during the life of the globally recognised architect Louis I. Kahn (Choudhury and Bell, 2011). Louis I. Kahn was commissioned for the project in 1962 and continued the design until his death in 1974. The project was completed in 1983 and is located in the heart of the city in an area now called Shere-Bangla-Nagar. This land was originally flat farmland on the northern outskirts of the old city of Dhaka (Choudhury and Bell, 2011). The total complex is comprised of the Citadel of Assembly and the Citadel of Institution. The Citadel of Assembly consists of the main assembly building plus the housing for Members of Parliament. The assembly building remains the focus of the complex, which is surrounded by built form, open spaces, a lake, garden and parks. To the south of the assembly building is a public plaza, and to the north the Presidential Plaza (Ashraf, 1994). While the building is acclaimed worldwide, its inner essence as an edifice transcends its artistic, functional, and structural role. The broader meanings of monumental buildings incorporate issues like power, control, politics, ethics and other critical issues. According to Stea (1993), architecture should be perceived beyond its physical and aesthetic entity and should incorporate a wider picture.

Vale argues that grand symbolic buildings like Jatio Sangsad Bhaban need to be understood from their political and cultural aspects: "Grand symbolic state buildings need to be understood in terms of the political and cultural contexts that helped to bring them into being" (2008, p. 3). This paper attempts to construct, reconstruct and summarise the cultural, socio- political, historic, moral, and ethical meanings attributed to this building from various published sources in relation to this symbolic building. Cultural aspects include its symbolic presence reflecting the democracy of independent Bangladesh, and the dramatic representation of the rural landscape and deltaic plain through its modern articulation of form and surroundings. The building also reflects Mughal built heritage through its geometrical articulation. The political meaning revolve around its appearance as an entity of West Pakistan President Ayub Khan's autocratic subject, which in through twists and turns became the symbol of nationalist elements for independent Bangladesh. The political meaning also hinges around the commissioning of JSB and its connection to the cold war politics. The historic meaning of JSB refutes the claim of its American imperialist connection and instead provides an insight that connects its position as more of a British Colonial urban planning imprint. The work also sheds a new light regarding commissioning of local architect Muzharul Islam as a precursor of the lead architect Louis Kahn. 
Finally, in revealing multiple subjective meaning of JSB, the paper draws upon sources. Superior prudence denotes complete selflessness; prudence, a combination of selflessness and self-interest; and imprudence a complete interest in issues.

\section{Multiple Meanings of Architecture}

The existence of multiple dimensions in architecture is widely recognised in the contemporary architecture discourse. Where architect Louis Kahn's and client General Ayub Khan's role was scrutinised regarding ethical concerns of the project. Revealing all these critical aspects of JSB is a central theme of this paper. It is well accepted that multiple meanings transcend the conventional idea of architecture as a mere structure (Whyte, 2006). Diverse meanings not only represent architecture with symbolism but also a connection with the larger landscape of the social fabric and social milieu (Upton, 2002). Goodman writes: "A building, more than most works, alters our environment physically; but moreover, as a work of art it may, through various avenues of meaning, inform and recognise our entire experience. Like other works of art - and like scientific theories, too - it can give new insight, advance understanding, participate in our continual remaking of a world" (Goodman, 1985, p. 652). In this setting, the various meanings of Jatio Sangsad Bhaban apart from its architectonic meaning, provide new insights and perceptions, and expose its multi-dimensional symbolic nature. For Dunougho, "Architecture exhibits wealth of symbol" (Donougho, 1987). Similarly, Whyte discusses the ways in which architecture conveys social, intellectual, and political meaning through symbolic expression (2006).

The multiple meanings of architecture are revealed 'in the eye' and emotional response or feelings of the beholder. Davis (1999) argues that depending on individual characteristics and views of the critic, the building unfolds itself; the experience of the beholder is inextricably connected to his or her strong feelings for the building from a social standpoint (Davis, 1999). Alexander et al. (1977) discusses this connection to feeling, saying that the core of architecture is feeling diverse understandings. An individual's societal understanding about architecture differs from person to person and from context to context (Alexander et al., 1977). For Shawcroft (1960), the potential evocative feeling depends upon the observer - an architect may respond in one way, a historian in another way (Shawcroft, 1960). He states, "with-out this power or quality to evoke feeling, a work of architecture is a mere image on the retina of the eye" (Shawcroft, 1960, p. 10). In his seminal article 'Architecture and Meaning', Hershberger (1970) delineated various theories of architectural meaning revolving around perspectives of the 'representational' and 'responsive'. The following sections will discuss different subjective meanings of Jatio Sangsad Bhaban in order to reveal the multiple socio-political meanings attributed to it.

\section{Multiple Meanings of Jatio Sangsad Bhaban}

The multiple meaning of JSB including a range of cultural, political, historical, and ethical issues reflect a diversity of human aspects surrounding this iconic structure from different views and perspectives. Two key individuals (the client Ayub khan and architect Louis I Kahn), the passing generation of Bengal people, key global player of politics such as the United States of America are inextricably associated with this iconic piece of architecture as an agent of society. An association of all cross sections of people and institutions have enriched and glorified the multiple socio-political meanings now embedded in JSB. Gieryn (2002) asserts "to some degree, every design (Architecture) is a blueprint for human behaviour and social structure" (Gieryn, 2002, p. 42). The discussion in this paper about the cultural, political, historical, moral, and ethical meanings of Jatio Sangsad Bhaban resonates with Gieryn's idea. This paper in its examination of the alternative meanings of this important building reinforces Blendell and Till's (2005) claim that "Architecture needs to be understood within a broader framework than the surface of image, both in terms of engaging with context and in terms of engaging with all the senses, through time and experience of use" (Blendell et al., 2005, p. xv).

The Cultural Meaning of Jatio Sangsad Bhaban: In order to establish the connection between architecture and culture, Lang et al. (1997) described architecture as the carrier of symbolic messages about one's nationality and culture. Gordon and Osborne (2004) argue that monuments are vehicles in symbolic expression of national values, culture and identities (Gordon and Osborne, 2004). For Goldberger (2009), "architecture is the ultimate physical representation of a culture, more so than even its flag" (Goldberger, 
2009, p. 16). Davis (1999) draws the connection between architecture and culture, asserting, "On the one hand, building exists as stand-alone artefacts, and on the other, they are artefacts that express the deep meaning, aspirations, and social order of a culture" (Davis, 1999, p. 95). The cultural meaning of Jatio Sangsad Bhaban mainly revolves around its value as a symbol of national identity for the people of Bangladesh. Jatio Sangsad Bhaban is an expression of national pride and national sentiment that unifies the people of Bangladesh (Choudhury and Armstrong, 2012). In its most basic form, it demonstrates the democratic culture of the Bengal people through its everlasting presence (Ksiazek, 1993). Apart from its metaphysical symbolic value of representing culture, Jatio Sangsad Bhaban resonates with the rural culture of Bengal though its physical manifestation of form and space.

Bangladesh is a deltaic plain curved out from a rich fusion between land and water. Its vast flat land with freeflowing rivers and canals provide a unique setting for architecture. Commonly found rural huts, which are at the core of Bengal rural culture, reconfigure the already rich mosaic of the Bengal landscape (Choudhury and Armstrong, 2012). Ashraf writes, "Architecture is inherently a landscape event" (Ashraf, 2007, p. 48). Architect Louis I. Kahn consciously incorporated the richness of the rural setting in Jatio Sangsad Bhaban as its essential form represents the rural hut while the landscape, incorporating an artificial lake, represents the Bengal delta. Kahn wrote, "I've chosen to distinguish [the national Assembly] from its surroundings by the introduction of a lake.

Because it's a delta country, and all important buildings [especially rural huts] are on mounds" (Ksiazek, 1993, p. 432). The deep rooted cultural articulation of this region, especially the geometry of the Mughal garden, has been reflected through the landscape of Jatio Sangsad Bhaban. The octagonal form and layering of building envelopes are reminiscent of a traditional Mughal approach to public buildings in the region ${ }^{\mathrm{ii}}$ (Ksiazek, 1993, p. 432). The brick structure of the subsidiary surrounding buildings resonates and reverberates with the traditional terracotta and brick structures of the region. Kahn consciously translated the traditional building culture of this region into a Western vocabulary in the creation of the Jatio Sangsad Bhaban (Ksiazek, 1993). As such, Jatio Sangsad Bhaban can be perceived as a physical representation of Bangladeshi and regional culture, identity and way of life.

The Political Meaning of Jatio Sangsad Bhaban: Jatio Sangsad Bhaban is a highly politically charged masterpiece with local politics playing a crucial part in its creation (Choudhury and Bell, 2011). The pervasive role of politics over architecture has been widely recognized in the literature. Hurst (2005) asserts that architecture should be understood from an all-encompassing perspective, incorporating 'power' and 'social significance' (Hurst, 2005). Others such as Vale (2008) visualized that, in general, all significant architectural commissions evolved from political underpinnings (Vale, 2008). Findley's idea (2005) reinforced this standpoint, as he asserts that the discipline of architecture mainly fulfils the desire and whim of those who possess power (Findley, 2005). Findley (20050 states that colonialism cast a deep shadow over the sphere of colonial architecture. Jatio Sangsad Bhaban was commissioned by the military dictator President Mohammad Ayub Khan of Pakistan in 1962, firmly placing it within a political and colonial construct of the time (Choudhury and Bell, 2011). Khan's motivation for the commission was to demonstrate his awareness of the importance of democracy for the people of East Pakistan. Now the sovereign Bangladesh (Choudhury and Bell, 2011).

In commissioning the building, Khan was mindful of his political survival. It has been argued that the selection of Dhaka as a site for Jatio Sangsad Bhaban emerged from the idea that the location would appease the hearts and minds of those from East Pakistan (Ksiazek, 1995). In the US Congress in 1961, Khan said, "our aim always was and always has been and always shall be to have representative institution" (Ksiazek, 1993, p. 428). Ksiazek's (1993) argument reinforces Khan's political maneuvering in connection to Jatio Sangsad Bhaban "Ayub Khan commissioned the complex to deflect criticism that his government is favoring West Pakistan over East" (Ksiazek, 1993, p. 428). Jatio Sangsad Bhaban is the result of formulation of Ayub Khan's 1962 Constitution and should be understood from a political standpoint (Vale, 2008). Schendel (2009) writes that in 1962 Ayub Khan promulgated a Constitution mainly to fulfil his political ambition for long-term rule (Schendel, 2009). He envisioned Dhaka as a seat of national assembly and Islamabad as the seat of the national government. Khans, political machination revolving Jatio Sangsad Bhban infuriated. People of East Pakistan, Schendel (2009) writes, "The military regime saw itself as stern, fair, constructive, efficient and 
avuncular. Most East Pakistanis, however, saw it as autocratic, imperialist, violent and geared to perpetuating the vice-regal power of Ayub Khan" (Schendel, 2009, p. 120).

The commissioning of Jatio Sangsad Bhaban is symbolic of the struggle of the Bengal people for selfdetermination and self-governance. In particular, it embodies the democratic values of the Bengal people. The building is the physical manifestation of democracy and embodiment of the essence of the Bangladeshi Constitution (Choudhury and Armstrong. 2012). Ksiazek compares Jatio Sangsad Bhaban to the Parthenon - it represents the democratic values of the Bengal people as the Parthenon represents the culture of Western democracy. Ksiazek (1993) writes, "[that] the national assembly building was intended to embody democratic ideals is everywhere apparent in Kahn's statements about the project" (Ksiazek, 1993, p. 428). Jatio Sangsad Bhaban has a significant role as both a symbol of oppression and as an emblem of democracy. The dual role of this nationalist building parallels the dual character of nationalism (Choudhury, Armstrong, 2013). The pre-liberation image of Jatio Sangsad Bhaban as a vehicle of oppression questions its symbolic representation of the hopes and aspirations of the Bangladeshi people.

Adds interest and complexity to its layers of political meaning. Jatio Sangsad Bhaban also emerged as a significant masterpiece as a product of a complex geopolitical agenda. It is argued that this iconic building is an outcome of the Smith-Mundt Law, alternately known as the US Information and Cultural Exchange Act (Choudhury and Armstrong, 2013). According to the Act, during the period of the Cold War, local elites were encouraged to take up higher studies in United States in order to consume American culture and practice, which they would expect to exercise in their own land (Choudhury and Armstrong, 2013). Kahn's engagement in Jatio Sangsad Bhaban is an indirect result of American Cold War policy (Choudhury and Armstrong, 2013).

The Historic Meaning of Jatio Sangsad Bhaban: This section critically considers archival and historic documents and. King's theory (1976) on colonial urban development (Choudhury and Armstrong, 2013) so as to articulate the historic meaning of Jatio Sangsad Bhaban. The extant literature suggests that Jatio Sangsad Bhaban ostensibly demonstrates the imposition of American neo-colonial ideas and order (Ksiazek, 1993). Ksiazek (1993) states in this regard: "Clearly, in the case of the complex at Dhaka, this dynamic indicates a colonial mentality, in which the ideals of a greater power are transposed onto one unlikely to resist. Does this make Sher-E-Bangla Nagar an example of American post-war cultural imperialism?" (Ksiazek, 1993, p. 435). This immediate assumption can be contested using the archival documents collected from the Public Works Department in Bangladesh and King's constructs of culture, technology and power structure (King, 1976). The archival documents and interviews clearly indicate that Louis I. Kahn was commissioned through an impartial selection of architects. ${ }^{\text {iii }}$ In the document 'The Second Capital' published on the Independence Day of Pakistan, 1964, it is clearly stated that three Western architects, Le Corbusier (French), Alvar Aalto (Finnish) and Louis I. Kahn, were invited initially.

The document states: "The Central Ministry of Works chose 3 eminent Architects, namely Le-Corbusier of France, Prof. Alvar Aalto of Finland and Prof. Louis I. Kahn of United States, to consider one of them as the Architect of the Second Capital. These Architects are leaders of architectural thought and are respectful of the traditions of Architecture and its principles and have by their works shown to be capable of expressing a way of life. Conditions and circumstances favoured the selection of Prof. Louis I. Kahn." (Pakistan Public Works Department Report 1964, p. 4). According to some literature, Le Corbusier declined the offer, Alvar Aalto fell ill and Louis I. Kahn was commissioned by default (Choudhury and Bell, 2011). The Public Works archival documents also ruled out that there was any possibility of appointment of local architect, Muzharul Islam, prior to the commissioning of Louis I. Kahn.iv Choudhury and Armstrong describe the commissioning of Jatio Sangsad Bhaban in East Pakistan (later Bangladesh) in 1962 during the British post-colonial period as more a product of colonial urban development rather than of American neo-colonialism. King's 1976 theory of colonial urban development incorporates three components: culture, technology, and the power structure of colonialism redefining the historic meaning of Jatio Sangsad Bhaban (Choudhury and Armstrong, 2013).

The first component, culture, reveals the theory of colonial third culture with its distinctive value and belief system, its own institutions, social structure and social relationships (King, 1976). Ayub Khan, the client in the commissioning of Jatio Sangsad Bhaban, can be considered a product of a third culture comprising of British and South Asian cultures (Choudhury and Armstrong, 2013). King's second component revolves 
around technological and industrial advancement and identity. Jatio Sangsad Bhaban ushered in a new era in terms of building technology in Bangladesh and thus represented the second component of King's colonial concept of urban development. King argues that; "The third element inherent in the concept of colonial urban development is the dominance-dependence relationship" (King, 1976, p. 37). This is evident in Kahn's design, in which the dominant function of the 'Citadel of Assembly' (The main Assembly Building) is separated from the subordinate or dependent function of the 'Citadel of Institution' (consisting of stadia, markets and museums, which were later not built) (Ksiazek, 1995). Thus, in addition to archival documents, all three components of colonial urban development have been instrumental in reshaping and refashioning the historic meaning of Jatio Sangsad Bhaban.

\section{Ethical and Moral Meaning in Connection to Jatio Sangsad Bhaban}

This section discuss the ethical and moral issues in relation to the participation of the two key players in Jatio Sangsad Bhaban - Louis I. Kahn and Ayub Khan. They argue that the underlying story of Jatio Sangsad Bhaban hinges on the personal gain of individuals, and may be viewed as one of self-interest and self-gain through a symbolic material object (Choudhury and Bell, 2011). The approach by Choudhury and Bell (2011) constitutes a new idea in regard to client and architect engagement in reconstructing existing notions and feelings. They delve into the concept of self-interest, turning to Adam Smith and his theory of self-interest in human nature. According to Smith, there are three aspects of self-interest: superior prudence, prudence, and imprudence (Smith, cited in Choudhury and Bell, 2011). Superior prudence denotes complete selflessness; prudence, a combination of selflessness and self-interest; and imprudence a complete interest in issues. The ethical dilemma of client Ayub Khan and architect Louis I. Kahn is somewhat prudent as it is directed to their fortune, power, image and reputation, which can be considered as a vehicle for their own tangible or intangible benefit. However, their prudent approach of self-interest may have helped to shape Jatio Sangsad Bhaban and this may not otherwise have been possible (Choudhury and Bell, 2011).

Alternatively, "Khan (the client) might have been elevated to the rank of superior prudence if he had: integrated Jatio Sangsad Bhaban within a futuristic nationalistic vision; and had expressed his concern about the masterly creation of the building not only its execution" (Choudhury and Bell, 2011, p. 110). However, Khan was a prudent rather than imprudent actor and his Islamic cultural values did not factor in Louis I. Kahn's design (Choudhury and Bell, 2011). In contrast, Kahn (the architect) could have reached the level of superior prudence if he had questioned the underlying purpose of the creation of Jatio Sangsad Bhaban, which was entirely political, rather than architectural (Choudhury and Bell, 2011). Kahn failed to understand the building's context in the light of the independence movement of Bangladesh (Choudhury and Bell, 2011). While it was expected a person of his stature would have supported the independence movement of Bangladesh, he did not (Choudhury and Bell, 2011). As Martin et al. point out, "a professional of high quality remains a role model to his fellow professionals, such a role model is not perceived as an expert, but as a person" (Martin et al., 2010, p. 2).

\section{Conclusion}

The contribution of Jatio Sangsad Bhaban is reflected in the depth of its intrinsic and extrinsic meanings. Its intrinsic meanings are revealed in its spatial and visible forms which are acclaimed worldwide and extrinsic meanings through its connection to history, culture, society and politics. The various multiple meanings of Jatio Sangsad Bhaban as summarised in this paper aim to generate new perceptions, evoke new thoughts and provide new insights thus enhancing its symbolic nature. Jatio Sangsad Bhaban conveys cultural, political, social and intellectual meaning as a symbolic and metaphoric expression. An iconic building that bears such a heavy weight of symbolism is expected to provoke controversy and generate question. As the Acropolis is an expression of the meaning of social and religious practice in Greece as well as wider democracy (Rhodes, 1995).

So there are multiple meanings for Jatio Sangsad Bhaban, the 'Acropolis of Bangladesh'. The Jatio Sangsad Bhaban is revered as a democratic emblem whose very meaning has not been contradicted or contested. This paper however raises issues that may not please many of the Jatio Sangsad Bhaban and Louis I. Kahn followers. However, the success of this paper lies not in shedding light on the positive aspects of the Jatio 
Sangsad Bhaban, but to the extent it moves the reader. It divulges the complex meaning of the Jatio Sangsad Bhaban and aims to add diversity and richness to its meaning. Without meaning, a building cannot aspire to become architecture (Hershberger, 1970). As such, without controversy, complexity and contradiction the distinct identity and dignity of the Jatio Sangsad Bhaban cannot stand out.

\section{Notes:}

${ }^{\text {i }}$ According to archival records, initially 200 acres of land was allocated which was later increased to 1,000 acres of land.

ii Before the design of Jatio Sangsad Bhaban, Kahn visited all Mughal landmarks in India and was inspired by the beauty and geometry of Mughal public buildings (Ksiazek, 1993).

iii The document was collected from the Public Works Department in Bangladesh. One of the authors of this article conducted an interview with engineer Shahidullah, one of the partners of Muzharul Islam, who was instrumental in the commissioning process of JSB. Also interviewed was the previous Chief Architect of the Public Works Department, Government of Bangladesh, A.S.M. Ismail, in connection to the commissioning of the architect. Both of them discarded the notion of cultural imperialism from America or that the commission was connected to a foreign aid project.

iv Both the interviewees (engineer Shahidualla (an associate partner of architect Muzharul Islam from 19641970 in Vastukalabid) and Chief Architect A.S.M. Ismail) also discarded the story of commissioning of local architect Muzharul Islam.

\section{References}

Alexander, C. \& Ishikawa, S. et al. (1977). A Pattern Language: Towns, Buildings, Construction. New York, Oxford University Press.

Ashraf, K. K. (2007). Taking Place: Landscape in the Architecture of Louis Kahn. Journal of Architectural Education, 61(2), 48-58.

Ashraf, K. K. (1994). Louis I. Kahn: National Capital of Bangladesh, Dhaka, Bangladesh, Global Architecture, 72(1994)1-47.

Blendell Jones, D. P. \& Till, J. (Eds) (2005). Architecture and Participation. New York, Spon Press.

Choudhury, B. I. \& Bell, G. (2011). The Engagement of Khan and Kahn in Jatio Sangsad Bhaban, Architecture Plus Design, 28(4), 104-111.

Choudhury, B. I. \& Armstrong, P. (2012). Monuments and Architecture Shaping Bangladeshi Identity. Global Built Environmental Review, 8(3), 45-67.

Choudhury, B. I. \& Armstrong, P. (2013). Jatio Sangsad Bhaban: A Legacy of British Colonial Urban Development or American Cultural Imperialism? Global Built Environmental Review, 8(3), 22-55.

Choudhury, B. I. \& Armstrong, P. (2013). The Geopolitics of Jatio Sangsad Bhaban in the Cold War Era, GSTF International Journal of Engineering and Technology, 2(1), 22-28.

Choudhury, B. I. \& Armstrong, P. (2013). JSB and Notions of American Cultural Imperialism in the Cold War Era. Proceedings of ACE (Architecture and Civil Engineering Conference), 49-156, Singapore.

Davis, H. (1999). The Culture of Building. Oxford, Oxford University Press.

Donougho, M. (1987). The Language of Architecture. Journal of Aesthetic Education, 21(3), 53-67.

Findley, L. (2005). Architecture, Politics and Cultural Agency. New York, Routledge.

Gieryn, T. F. (2002). What Buildings do? Theory and Society, 31(1), 35-74.

Goodman, N. (1985). How Buildings Mean. Critical Inquiry, 11(4), 642-653.

Goldberger, P. (2009). Why Architecture Matters. New Haven, Yale University Press. 
Gordon, D. L. A. \& Osborne, B. S. (2004). Constructing National Identity in Canada's Capital, 1900-2000: Confederation Square and the National War Memorial. Journal of Historical Geography, 30(4), 618642.

Hershberger, R. G. (1970). Architecture and Meaning. Journal of Aesthetic Education, 4(4), 37-55.

Hurst, P. (2005). Space and Power: Politics, War and Architecture. Cambridge, Polity Press.

King, A. D. (1976). Colonial Urban Development: Culture, Social Power, and Environment. London; Boston: Routledge \& Paul.

Ksiazek, S. (1993). Architectural Culture in the Fifties: Louis Kahn and the National Assembly. Society of Architectural Historians, 52(4), 416-435.

Ksiazek, S. W. (1995). Changing Symbol in Public Life: Louis Kahn's Religious and Civic Projects 1944-1966 and Architectural Culture at the End of the Modern Movement. Unpublished PhD, Department of Architecture and Planning, Colombia University, New York.

Lang, J. T. \& Desai, M. et al. (1997). Architecture and Independence: The Search for Identity — India 1880 to 1980. Delhi; New York: Oxford University Press.

Martin, C., Vaught, W. \& Solomon, R. C. (Eds) (2010). Ethics across the Professions: A Reader for Professional Ethics. New York, Oxford University Press.

Pakistan Public Works Department Report. (1964). Dhaka, Associated Printers Limited.

Rhodes, R. F. (1995). Architecture and Meaning on the Athenian Acropolis. Cambridge, Cambridge University Press.

Shawcroft, B. (1960). Architecture and the Layman. Journal of Architectural Education, 15(2), 10-14.

Stea, D. (1993). Placemaking. Sydney, Avebury.

Schendel, W. V. (2009). A History of Bangladesh. Cambridge, Cambridge University Press

Upton, D. (2002). Architecture in Everyday Life. New Literary History, 33(4), 707-723.

Vale, L. J. (2008). Architecture, Power, and National Identity. London; New York: Routledge.

Whyte, W. (2006). How Do Buildings Mean? Some Issues of Interpretation in the History of Architecture. History and Theory, 45(2), 153-177. 